\title{
Potential impact of the main benthic amphipods on the eastern Weddell Sea shelf ecosystem (Antarctica)
}

Accepted: 19 March 2001 / Published online: 6 June 2001

(C) Springer-Verlag 2001

\begin{abstract}
As they represent one of the most diversified taxonomic groups on Antarctic bottoms, amphipods are likely to play a complex role in biogeochemical fluxes that occur within benthic ecosystems. The aim of this paper is to present, using both digestive tract analyses and relative species abundance data, the impact of amphipod feeding on different potential preys of the Weddell Sea. The study is based on data obtained for 29 representative amphipod species collected at 130 stations distributed along the eastern shelf of the Weddell Sea (depth range: 60-2,000 $\mathrm{m}$ ) during three summer cruises, from 1989 to 1998. Sedimenting plankton particles (10$27 \%$ ), crustaceans $(22-32 \%)$ and fish carrion (5-18\%) are the main food resources. Other abundant potential preys, such as molluscs or tunicates, do not seem to be consumed. Variations in the proportions of the different preyed food items are observed, mainly related to differences in relative amphipod species composition in samples. Presented results will help in refining ecological models of the prospected area, but also underline the need for accurate and reliable measurements of the feeding rates of Antarctic benthic organisms.
\end{abstract}

\section{Introduction}

In a recent attempt to model the organic matter flows within the benthic communities of the Weddell Sea continental shelf (Jarre-Teichmann et al. 1997), biologists of the Alfred-Wegener Institute (Bremerhaven,

This paper presents results of the Midterm Symposium of the SCAR programme "Ecology of the Antarctic Sea Ice Zone" (EASIZ). This manuscript was edited by W. Arntz and A. Clarke.

P. Dauby $(\bowtie) \cdot$ Y. Scailteur · G. Chapelle $\cdot$ C. De Broyer Laboratoire de Carcinologie,

Département des Invertébrés,

Institut Royal des Sciences Naturelles de Belgique (IRScNB), rue Vautier, 29, 1000 Brussels, Belgium

E-mail: dauby@kbinirsnb.be
Germany) underlined the need for a better understanding and for an accurate measurement of several key processes that govern biogeochemical fluxes in these ecosystems. Among these processes, those related to nutrition of benthic organisms (like food intake or assimilation rates) are of primary interest.

Within the Southern Ocean benthic ecosystems, crustaceans are by far the most speciose taxon (Arntz et al. 1997) and, among crustaceans, amphipods represent the richest group, with more than 820 recorded species (De Broyer and Jazdzewski 1993, 1996), about 320 of which inhabit Weddell Sea waters. These peracarids have colonised a wide variety of ecological niches, from epontic to below-ground biotopes. They achieved a successful eco-ethological diversification, occupying apparently almost all the possible micro-habitats and developing various feeding strategies, from suspensionfeeding to scavenging on vertebrate carcasses. Indeed, in a recent study (Dauby et al. 2001), we showed that at least eight different feeding types occurred among Weddell Sea gammaridean amphipods (despite the absence of macro-herbivory owing to the lack of benthic macroalgae in that area), including some specialised modes such as micro-predatory browsing on invertebrate colonies.

In this study, we try to answer the questions: what do amphipods eat (what is the share of every potential food in their diet), and also, what is their impact on the different available food sources? We then analyse the role of the Weddell Sea amphipod taxocoenosis in consuming these food sources, taking into account their food preferences and their in situ relative occurrence. The presented results are, however, limited to the austral summer season and are thus not likely to represent a year-round situation.

\section{Materials and methods}

Amphipods were collected from benthic and suprabenthic samples taken in the eastern Weddell Sea during three Antarctic summer RV "Polarstern" cruises: EPOS leg 3 (1989; Arntz et al. 1990), 


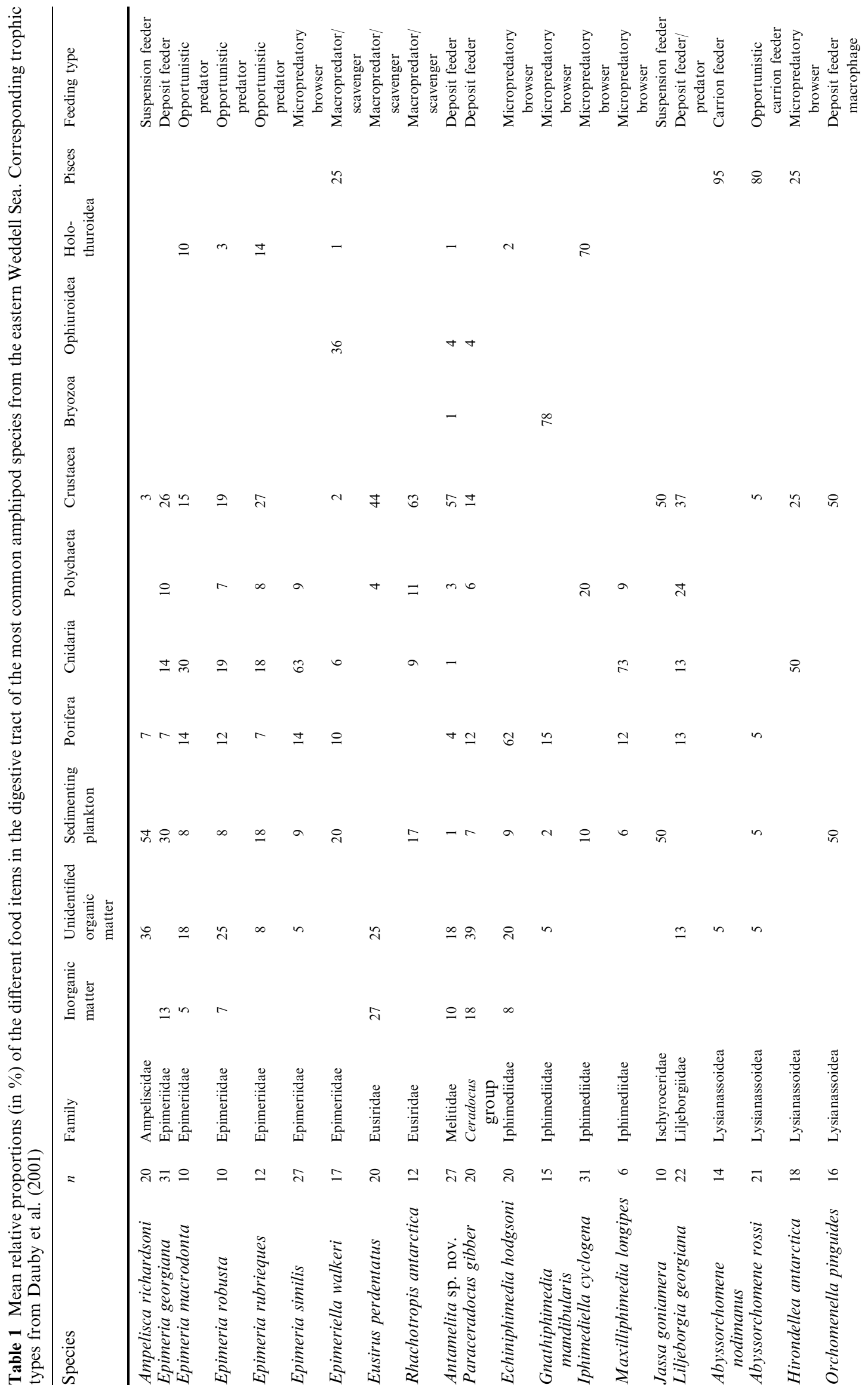




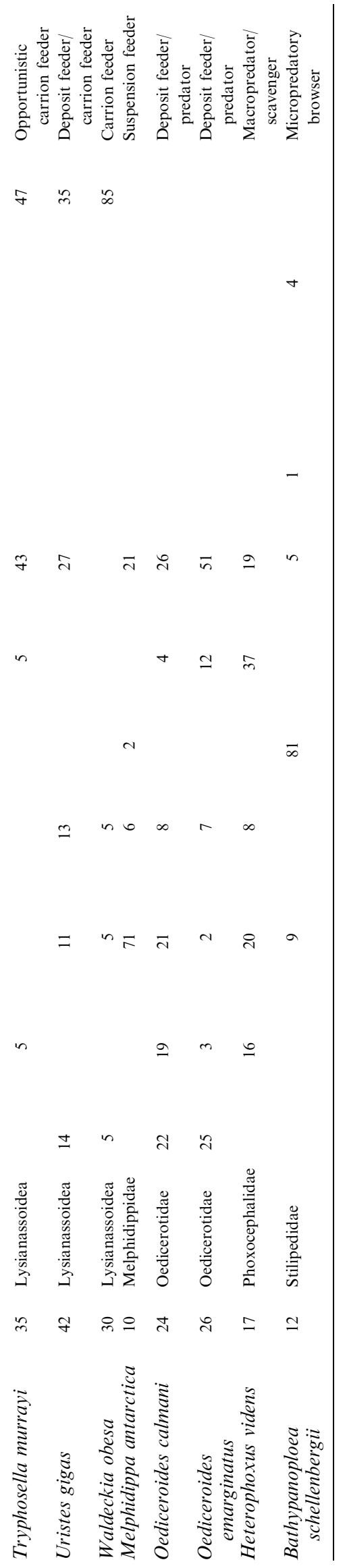

EASIZ I (1996; Arntz and Gutt 1997) and EASIZ II (1998; Arntz and Gutt 1999). In total, 130 catches provided amphipod material in water depths from $60 \mathrm{~m}$ down to $2,000 \mathrm{~m}$. Gears used included Agassiz, benthopelagic and bottom trawls, dredges, epibenthic sledges, TV grabs, giant and multibox corers, and baited traps.

Ethological observations (food detection and capture, mobility patterns) were performed with living specimens of about 40 species kept in cool containers on board and afterwards in a cool laboratory at IRScNB, Brussels. Amphipods (between 25 and $>100$ individuals, depending on species) were maintained at a temperature of $-1^{\circ} \mathrm{C}\left( \pm 1^{\circ} \mathrm{C}\right)$ in 2- to $30-1$ aquaria. Feeding experiments were performed in these aquaria, using as potential food source different living organisms (like crustaceans, echinoderms or plankton) or dead material (such as pieces of amphipods, fishes or squid) laid on the bottom or offered with forceps. These experiments were usually conducted over periods of $6-8$ weeks.

Amphipod gut content analyses were done mainly on specimens fixed just after sampling in $4 \%$ formaldehyde. The amount of food in the stomach $\left(C_{s}\right)$ and gut $\left(C_{g}\right)$, respectively, was coded with arbitrary scores $(4$, more than $75 \%$ of the volume is filled; 3 , from 50 up to $75 \% ; 2$, from 25 up to $50 \%$; 1 , less than $25 \%$ ). Every item present in the digestive tract was determined to the group or species level when possible, and their proportion was coded using a similar coefficient $\left(P_{s}, P_{g}=1,2,3\right.$ or 4$)$. A semi-quantitative approach, inspired from the "percentage points" method (Hynes 1950; Williams 1981), was used, with the following equations:

$I(i)=\sum_{n=1}^{x} C_{s}(n) * P_{s}(n)+C_{g}(n) * P_{g}(n)$

where $I(i)$, dimensionless, is the importance of item $i$ in the diet of a given species, and $x$ the number of specimens dissected;

$R(i)=\frac{I(i)}{\sum_{n=1}^{y} I(n)} * 100$

where $R(i)$, in $\%$, represents the relative importance of item $i$ in the total diet of a given species, and $y$ the number of different items.

The trophic impact of these amphipod species on Weddell Sea ecosystems has been evaluated by coupling feeding preferences and relative species abundances with the basic formula:

$T(i)=\sum_{s p=1}^{x} \frac{\bar{N}_{s p}}{\bar{N}_{t o t}} * R(i)_{s p}$

where $T(i)$ is the trophic impact on food item $i$ (in \%), $x$ the number of analysed species, and $\bar{N}$ the mean number of individuals of a defined species ( $s p$ ) and of all the $x$ analysed species (tot) for all the samples of a cruise. Only classical benthic sampling devices (trawls and box corers) were taken into account for evaluating $\bar{N}$, as baited traps, for instance, do not reflect the actual instantaneous abundance of a species in a defined sampling area.

\section{Results}

The mean relative abundance $[R(i)$, in \%] of the different food items in the digestive tract of the most important Weddell Sea amphipod species is presented in Table 1, with information about their principal feeding types. The latter, determined from both digestive tract analyses and behavioural observations, are extensively described in Dauby et al. (2001).

The 29 amphipod species selected for the present evaluation were chosen on the basis of their relative abundance, each one representing at least $0.4 \%$, on average, of the total amphipod population collected during each cruise. For the EPOS cruise (1989), these 29 
species represent $52.8 \%$ of total amphipods $(58 \%$ of all the samples were analysed) while, for the EASIZ I cruise (1996), they represent $70.9 \%$ of total amphipods $(82 \%$ of the samples were investigated).

The amphipod trophic impact on the different available food items $[T(i)]$ of the Weddell sea is presented in Table 2, for the EPOS and the EASIZ I cruises, respectively.

For the EPOS samples, crustaceans appear to be the most frequently consumed items (32\%), followed by fish carcasses $(18 \%)$. If we do not take into account the unidentified organic matter (unrecognisable organic bodies without any specific features like cnidocysts, or without any hard structures like chitinous plates or spicules), particles of planktonic origin represent the third most common item. Sponges, cnidarians and worms (polychaetes and nematodes) are about equally consumed $(5-7 \%)$, while bryozoans and echinoderms represent only a tiny fraction of the amphipod diet.

Results from the EASIZ I cruise are rather different. Plankton-originating cells (together with the unidentified matter) are the main dietary component $(27 \%)$, before crustaceans $(22 \%)$. Fish flesh constitutes only a small fraction $(5 \%)$, and is of the same order of occurrence as worms, bryozoans or holothuroids. Sponges, with $7 \%$, are the third item in importance in the amphipod diet.

\section{Discussion}

In their recent effort to summarise into a conceptual flow diagram the trophic interactions that occur on Weddell Sea bottoms, Jarre-Teichmann et al. (1997) admitted that crustaceans form a "very heterogenous box". Literature on high-Antarctic amphipod feeding strategies is indeed scarce (Oliver and Slattery 1985; Slattery and Oliver 1986; Coleman 1989a, b, c, 1990a, b; Klages and Gutt $1990 \mathrm{a}, \mathrm{b}$ ), and is concerned with less than $5 \%$ of known species. Owing to this lack of knowledge, JarreTeichmann et al. (1997) arbitrarily attributed the following predation impacts to crustaceans in their model:

Table 2 Mean relative trophic impacts [T(i)] (in \%) of the eastern Weddell Sea benthic amphipod community on different potential food sources, during the EPOS (1989) and EASIZ I (1996) cruises. Inorganic material (sediment grains) were omitted from calculations

\begin{tabular}{lcc}
\hline & EPOS & EASIZ I \\
\hline Unidentified organic matter & 17 & 25 \\
Sedimenting plankton & 10 & 27 \\
Porifera & 7 & 7 \\
Cnidaria & 7 & 3 \\
Worms & 5 & 4 \\
Crustacea & 32 & 22 \\
Bryozoa & 2 & 3 \\
Ophiuroidea & 1 & 1 \\
Holothuroidea & 1 & 3 \\
Pisces & 18 & 5 \\
\hline
\end{tabular}

$10 \%$ polychaetes, $3 \%$ crustaceans, $4 \%$ echinoderms, $1 \%$ bryozoans and $82 \%$ detritus. From Tables 1 and 2, it clearly appears that such a $T(i)$ distribution is inappropriate. "Detritus"-feeders represent only one-half of the Weddell Sea amphipod species (Dauby et al. 2001) even when gathering together the deposit-feeders and all the occasional opportunistic scavengers of all types from micro-feeders to necrophages. The species used in JarreTeichmann et al.'s (1997) paper (Paraceradocus gibber, Gnathiphimedia mandibularis, Epimeria robusta, (Abyss-) Orchomene plebs and Bovallia gigantea) are not at all representative of the whole benthic amphipod community, and thus induce a bias in the model.

The present study shows that, when averaging over site and year variations, crustaceans, planktonic particles and carcasses form the bulk of the Weddell Sea amphipod diet. The other sources of feeding (worms, echinoderms, bryozoans or sponges) count for a minor part and are mainly consumed by some specialised predatory feeders.

The share between living and non-living food items is, however, sometimes difficult to establish. If it is relatively evident for, for example, fish muscles (although we have in very few cases observed cohorts of Lysianassoidea species attacking living fishes in the aquarium), it is not so obvious for items such as crustaceans. The presence of euphausiid remains in amphipod digestive tracts, for instance, would suggest a scavenging depositfeeding mode, but the occurrence of amphipod remains can be attributed to both a predatory and a scavenging feeding mode. Complementary in vivo observations of feeding behaviour are thus necessary.

Two groups of benthic animals which are well represented in the high Antarctic are apparently absent from the diet of amphipods: molluses (in terms of biodiversity, the second phylum after crustaceans; Arntz et al. 1997) and ascidians. The absence of these items could be related to their "protective" shell (although it is not much calcified in cold waters) or tunic. Such an argument is, however, not consistent, as some amphipod species are able to browse on holothuroid podia, on sponges or on bryzoan colonies. Some molluscs and ascidians may have been consumed, and may form part of the unidentified organic matter, which represents about one-fifth of the total ingested food, but no radula was found in amphipod digestive tracts.

The difference between the $T(i)$ distributions for the two cruises (Table 2) is likely to be attributed to differences in sampling areas, and concurrently in the sampled amphipod communities (De Broyer et al., in press). For instance, in the EPOS cruise, Uristes gigas, a scavenging lysianassoid, was abundant ( $>7 \%$ of total amphipods) in the samples, while in EASIZ I, one Ampelisca richardsoni, a typical suspension-feeder, was dominant $(22 \%)$. Such differences emphasise the need for multiple sampling with devices that give a better overview of the benthic community composition, such as corers.

In the same way, the results presented in Table 2 should be regarded cautiously, as the analysed amphi- 
pod species, albeit dominant in samples, are not necessarily the dominant species of the prospected areas. Indeed, owing to the gears used, larger species are significantly more numerous in the samples. Except for one species (Heterophoxus videns), all the amphipods we analysed are longer than the mean size $(17 \mathrm{~mm})$ for all known East Antarctic species. Moreover, all of them were adult specimens, and the diet of juveniles may be different.

The conversion of the measured trophic impacts into actual food consumptions requires knowledge of both biomass and feeding rate of the amphipods. Reliable biomass data (based on multibox corer sampling effort) for eastern Weddell Sea amphipods were only published by Gerdes et al. (1992) for cruises performed from 1987 to 1989 . The authors found a mean biomass of $669 \mathrm{mg}$ WW m${ }^{-2}$, with values ranging from 8 to $6,396 \mathrm{mg} \mathrm{WW}$ $\mathrm{m}^{-2}$ depending on the sampling station. Amphipods counted for about $5 \%$ of total benthic animal biomass. Feeding rate measurements, however, were never published for high-Antarctic amphipods, maybe because of the experimental complexity in feeding most of these crustaceans in culture conditions. Some attempts, however, have been made to indirectly estimate this feeding rate (for example, using $\mathrm{P} / \mathrm{B}$ ratios; Brey and Clarke 1993; Jarre-Teichmann et al. 1997), but these should be cautiously regarded. We have carried out some experimental series in aquaria on different necrophagous Lysianassoidea (De Broyer and Klages 1990; Y. Scailteur, G. Chapelle, C. De Broyer, unpublished work), and measured feeding rate values ranging from 14 to $40 \mathrm{mg} \mathrm{g}^{-1}$ day $^{-1}$, depending on species and prey. These values, however, are likely not applicable to the whole amphipod community, as necrophages are known to display a discrete method of feeding, depending greatly on food availability.

The present paper, hopefully shedding better light on the role of the amphipod taxocoenosis within the trophic flows which occur on the Weddell Sea bottoms, emphasises the necessity to amplify the research effort in at least two directions: a better knowledge of the benthic community structure (mainly species biomass estimates), and the development of techniques to accurately measure the organic matter fluxes at the individual (or population) level. Without such additional information, the elaboration of consistent ecosystem models, such as those presented, for example, by Rakusa-Suszczewski (1993) or Knox (1994), may remain at a standstill for a long time.

Acknowledgements The present research was performed under the auspices of the Scientific Research Programme on Antarctic (phase IV) from the Belgian State Prime Minister's Federal Office for Scientific, Technical and Cultural Affairs (OSTC contract no. A4/ $\mathrm{DD} / \mathrm{B} 02)$. Samples were collected during the European "Polarstern" study (EPOS), sponsored by the European Science Foundation, and during the EASIZ I and II campaigns, sponsored by the Alfred-Wegener-Institut für Polar- und Meeresforschung (A.W.I.), Bremerhaven, Germany. We are indebted to the officers and crews of $\mathrm{R} / \mathrm{V}$ "Polarstern" for the attention they paid in deploying sampling devices. We would also like to thank Professor
W. Arntz and Drs. D. Gerdes, M. Klages, T. Brey, J. Gutt (A.W.I.) and all the people who helped in collecting, sorting and analysing the samples.

\section{References}

Arntz WE, Gutt J (eds) (1997) The expedition ANTARKTIS XIII 3 (EASIZ I) of RV "Polarstern" to the Weddell Sea in 1996. Ber Polarforsch 249:148

Arntz WE, Gutt J (eds) (1999) The expedition ANTARKTIS XV/3 (EASIZ II) of RV "Polarstern" in 1998. Ber Polarforsch 301:229

Arntz WE, Ernst W, Hempel I (eds) (1990) The expedition ANTARKTIS VII/4 (EPOS Leg 3 ) and VII/5 of the R/V "Polarstern" in 1989. Ber Polarforsch 68:214

Arntz WE, Gutt J, Klages M (1997) Antarctic marine biodiversity: an overview. In: Battaglia B, Valentia J, Walton DWH (eds) Antarctic communities: species, structure and survival. Cambridge University Press, Cambridge, pp 3-14

Brey T, Clarke A (1993) Population dynamics of marine benthic invertebrates in Antarctic and Sub-Antarctic environments: are there unique adaptations? Antarct Sci 5:253-266

Coleman CO (1989a) On the nutrition of two Antarctic Acanthonotozomatidae (Crustacea: Amphipoda). Polar Biol 9:287-294

Coleman CO (1989b) Burrowing, grooming and feeding behaviour of Paraceradocus, an Antarctic amphipod genus (Crustacea). Polar Biol 10:43-48

Coleman CO (1989c) Gnathiphimedia mandibularis (KH Barnard 1930), an Antarctic amphipod (Acanthonotozomatidae, Crustacea) feeding on Bryozoa. Antarct Sci 1:343-344

Coleman CO (1990a) Two new Antarctic species of the genus Epimeria (Crustacea: Amphipoda: Paramphithoidae), with description of juveniles. J R Soc N Z 20:151-178

Coleman CO (1990b) Bathypanoploea schellenbergi (Holman \& Watling, 1983), an Antarctic amphipod (Crustacea) feeding on Holothuroidea. Ophelia 31:197-205

Dauby P, Scailteur Y, De Broyer C (2001) Trophic diversity within the eastern Weddell Sea amphipod community. Hydrobiologia 443:69-86

De Broyer C, Jazdzewski K (1993) Contribution to the marine biodiversity inventory. A checklist of the Amphipoda (Crustacea) of the Southern Ocean. Doc Trav Inst R Sci Nat Belg 73:1-155

De Broyer C, Jazdzewski K (1996) Biodiversity of the Southern Ocean: towards a new synthesis for the Amphipoda (Crustacea). Boll Mus Civ Stor Nat Verona 20:547-568

De Broyer C, Klages M (1990) Studies on amphipod biology. In: Arntz WE, Ernst W, Hempel I (eds) The expedition ANTARKTIS VII/4 (EPOS Leg 3) and VII/5 of the R/V "Polarstern" in 1989. Ber Polarforsch 68:113-115

De Broyer C, Scailteur Y, Chapelle G, Rauschert M (in press) Diversity of epibenthic habitats of gammaridean amphipods in the eastern Weddell Sea. Polar Biol

Gerdes D, Klages M, Arntz WE, Herman RL, Galéron J, Hain S (1992) Quantitative investigations on macrobenthos communities of the southeastern Weddell Sea shelf based on multibox corer samples. Polar Biol 12:291-301

Hynes HBN (1950) The food of the freshwater sticklebacks Gasterosteus aculeatus and Pygosteus pungitius, with a review of the methods used in studies of the food of fishes. J Anim Ecol 19:36-58

Jarre-Teichmann A, Brey T, Bathmann UV, Dahm C, Dieckmann GS, Gorny M, Klages M, Pages F, Plötz J, Schnack-Schiel SB, Stiller M, Arntz WE (1997) Trophic flows in the benthic community of the eastern Weddell Sea, Antarctica. In: Battaglia B, Valentia J, Walton DWH (eds) Antarctic communities: species, structure and survival. Cambridge University Press, Cambridge, pp 118-134

Klages M, Gutt J (1990a) Observations on the feeding behaviour of the Antarctic gammarid Eusirus perdentatus (Chevreux, 1912) (Crustacea: Amphipoda) in aquaria. Polar Biol 10:359-364 
Klages M, Gutt J (1990b) Comparative studies on the feeding behaviour of high Antarctic amphipods (Crustacea) in laboratory. Polar Biol 11:73-79

Knox GA (1994) The biology of the Southern Ocean. Cambridge University Press, Cambridge

Oliver JS, Slattery PN (1985) Effects of crustacean predators on species composition and population structure of soft-bodied infauna from McMurdo Sound, Antarctica. Ophelia 24:155-175

Rakusa-Suszczewski S (1993) Matter transport and budgets in the Admiralty Bay area. In: Rakusa-Suszczewski S (ed) The mari- time Antarctic coastal ecosystem of Admiralty Bay. Department of Antarctic Biology, Polish Academy of Science, Warsaw, pp 199-212

Slattery PN, Oliver JS (1986) Scavenging and other feeding habits of lysianassid amphipods (Orchomene spp.) from McMurdo Sound, Antarctica. Polar Biol 6:171-177

Williams MJ (1981) Methods for analysis of natural diet in portunid crabs (Crustacea: Decapoda: Portunidae). J Exp Mar Biol Ecol 52:103-113 